\title{
Michael Zank
}

\section{Jüdische Religionsphilosophie als Apologie des Mosaismus}

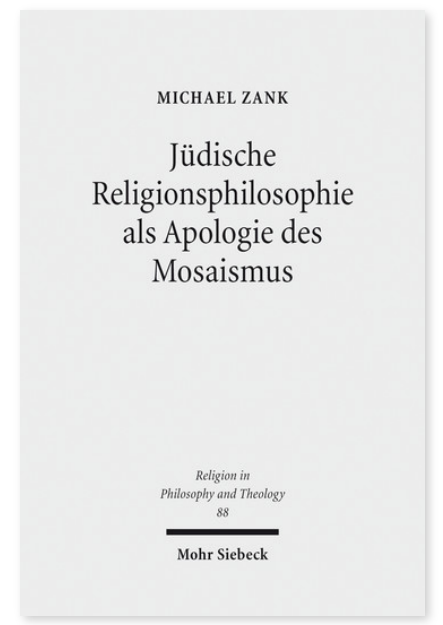

2016. X, 399 Seiten. RPT 88

ISBN 978-3-16-154734-8

DOI 10.1628/978-3-16-154734-8

eBook PDF $114,00 €$

ISBN 978-3-16-154733-1

fadengeheftete Broschur 114,00€
In zwanzig, hier zum großen Teil erstmals veröffentlichten, Aufsätzen und Vorträgen stellt Michael Zank die moderne jüdische Religionsphilosophie unter das Motto einer »Apologie des Mosaismus«. Er geht dabei sowohl thematisch als auch historisch vor und zeigt, wie sich Hermann Cohen, Franz Rosenzweig, Martin Buber, Leo Strauss und andere mit dem christlichen und philosophischen Erbe Europas auseinandergesetzt haben. Er denkt außerdem darüber nach, was wir aus jenen Auseinandersetzungen heute noch lernen können. Das Buch versteht sich als eine Einführung in die jüdische Religionsphilosophie. Die Idee für dieses Buch entstand, als der Autor als Martin Buber Professor für jüdische Religionsphilosophie an der Goethe Universität Frankfurt lehrte.

Michael Zank Geboren 1958; Studium der Ev. Theologie in Göttingen, Kiel und Heidelberg sowie Judaistik in Heidelberg und Jerusalem; Doktorat in Near Eastern and Judaic Studies an der Brandeis University (Waltham/Mass.); seit 1994 Professor für Religionswissenschaft an der Boston University und Direktor des Elie Wiesel Center for Jewish Studies.

\section{Jetzt bestellen:}

https://mohrsiebeck.com/buch/juedische-religionsphilosophie-als-apologie-des-mosaismus-9783161547348?no_cache=1 order@mohrsiebeck.com

Telefon: +49 (0)7071-923-17

Telefax: $+49(0) 7071-51104$ 